\title{
APLIKASI GEOTUBE SEBAGAI KONSTRUKSI ALTERNATIF PENANGGULANGAN EROSI AKIBAT GELOMBANG PASANG BONO
}

\author{
Andryan Suhendra'; Ganny Saputra ${ }^{2}$; Eric Rinaldo Kodrat ${ }^{3}$ \\ ${ }^{1}$ Manager Teknik PT Tetrasa Geosinindo dan Staf Pengajar Universitas Bina Nusantara \\ Civil Engineering Department, Faculty of Engineering, Binus University \\ Jl. K.H. Syahdan No. 9, Palmerah, Jakarta Barat 11480 \\ asuhendra@binus.ac.id \\ ${ }^{2}$ Staff Teknik PT Tetrasa Geosinindo \\ ${ }^{3}$ Mahasiswa Teknik Sipil Universitas Bina Nusantara, Jakarta
}

\begin{abstract}
Bono tidal current leads to silting of the river estuary. The impact is a change in river line of Muda Island due to erosion and deposition. One alternative construction to overcome such this erosion problem of is Geotube, a construction system that combines geosynthetic material for blanket and sand slurry material for filler. Analysis is performed to ensure the system is feasible through the use of Geocops software to determine the type of suitable geosynthetic material and other parameters such as pump pressure. Another analytical calculation performed is the calculation of the stability of global construction through the use of Slope/W software and the approximate amount of consolidation decrease occurred using one-dimensional consolidation theory, published by Terzaghi. This article also presents the process of field implementation including various obstacles encountered and the solutions. From the results of the analysis and the field implementation, it can be concluded that the use of Geotube system on this project provides satisfactory results and can be relied upon as an alternative construction of erosion problems.
\end{abstract}

Keywords: Bono tidal current, erosion, deposition, Geotube, geosynthetic material, sand slurry material, Geocops, Slope/W, consolidation theory

\begin{abstract}
ABSTRAK
Arus Pasang Bono mengakibatkan pendangkalan muara sungai. Dampaknya adalah perubahan garis pinggir sungai pada Pulau Muda akibat erosi dan deposisi. Salah satu alternatif konstruksi untuk menanggulangi permasalahan erosi ini adalah Geotube, yaitu sistem konstruksi yang memadukan material geosintetik sebagai pembungkus dan material slurry pasir sebagai material pengisi. Analisis dilakukan untuk memastikan sistem ini layak diaplikasikan melalui penggunaan software Geocops guna menentukan jenis material geosintetik yang sesuai serta parameter lainnya seperti tekanan pompa. Perhitungan analitis lain yang dilakukan adalah perhitungan stabilitas global konstruksi melalui penggunaan software Slope/W serta perkiraan besarnya penurunan konsolidasi yang terjadi menggunakan teori konsolidasi satu dimensi yang dipublikasikan oleh Terzaghi. Artikel ini juga menyajikan proses pelaksanaan di lapangan termasuk berbagai kendala yang dihadapi serta solusinya. Dari hasil analisis serta hasil pelaksanaan di lapangan, dapat disimpulkan bahwa penggunaan sistem Geotube pada proyek ini memberikan hasil yang memuaskan dan dapat diandalkan sebagai konstruksi alternatif penanggulangan permasalahan erosi.
\end{abstract}

Kata kunci: arus pasang Bono, erosi, deposisi, Geotube, material geosintetik, material slurry pasir, Geocops, Slope/W, teori konsolidasi 


\section{PENDAHULUAN}

Salah satu penyebab erosi atau abrasi sisi sungai adalah gelombang atau arus yang besar. Arus ini dapat mengakibatkan kerusakan pada konstruksi di sisi sungai. Salah satu fenomena gelombang besar ini adalah arus pasang bono. Pada Sungai Kampar terdapat muara sungai berbentuk seperti huruf "V", dimana massa air masuk melalui mulut teluk yang lebar kemudian tertahan sehingga air laut pasang memenuhi kawasan muara (Gambar 1). Massa air yang telah terkumpul itu kemudian terdorong ke arah hulu yang menyebabkan semacam efek tekanan kuat ketika melewati areal yang menyempit dan dangkal secara konstan di mulut teluk. Hal ini menimbulkan gelombang yang bervariasi pada hulu teluk. Tinggi gelombang yang terbentuk dapat mencapai $4 \mathrm{~m}$.

Beberapa jenis konstruksi proteksi erosi antara lain tumpukan batu, tetrapod, bronjong, atau sheet pile. Adapun konstruksi proteksi erosi tersebut di atas memiliki beberapa kekurangan, mulai dari kesulitan pelaksanaan konstruksi di lapangan, pengadaan material dan terutama dari segi tingginya biaya, hingga lamanya waktu konstruksi. Konstruksi sheetpile (Gambar 2) telah diaplikasikan tetapi kurang efektif dalam penanganan kasus ini.

Salah satu alternatif konstruksi proteksi erosi yang sesuai diaplikasikan pada kondisi ini adalah Geotube (Bergado, 2005, Chu et al., 2011, Koerner, 2005). Terkait dengan hal tersebut, akan ditinjau penggunaan material Geotube dengan tujuan menganalisis efektifitas penggunaan material Geotube sebagai alternatif konstruksi proteksi erosi dan memperkenalkan penggunaan sistem ini untuk keperluan di dalam negeri. Geotube adalah suatu konstruksi yang berbentuk selubung pipa besar yang diisikan material pasir di dalamnya. Selubung tersebut terbuat dari material geotekstil kuat tarik tinggi (high strength geotextile) dengan spesifikasi tertentu. Geotube ini telah diaplikasikan secara luas sebagai konstruksi pemecah gelombang, tanggul, revetment, groin, dan jetty. Berikut ini adalah gambaran umum konstruksi Geotube (Gambar 3). Pada prinsipnya, fungsi geosintetik sebagai pembungkus Geotube adalah menahan tanah atau campuran yang berada di dalam, tapi pada saat yang bersamaan harus dapat mengalirkan air keluar tanpa membawa butiran tanah dari dalam.

Material pengisi dialirkan ke dalam Geotube dengan bantuan pompa maupun dengan memanfaatkan gravitasi melalui inlet yang terdapat pada Geotube (Gambar 4). Material pengisi pada umumnya bersifat sangat cair/encer agar partikel tanah yang padat dapat dialirkan dengan mudah ke seluruh bagian dalam Geotube. Perbandingan campuran partikel padat dan cair umumnya memiliki perbandingan berkisar antara 1: 4 sampai 1:9.

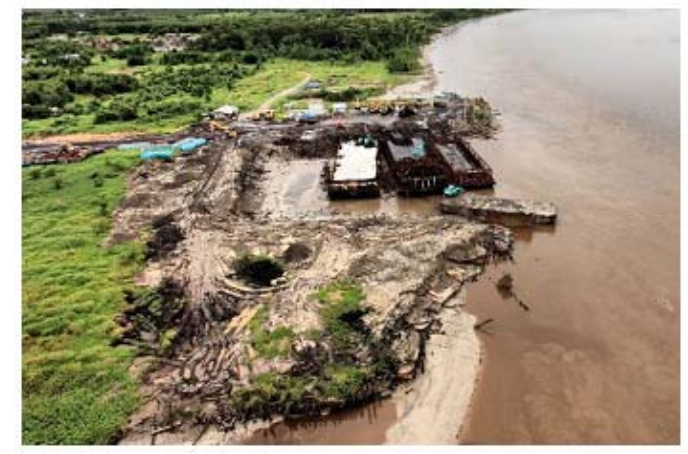

Gambar 1. Kondisi dermaga setempat akibat erosi arus Bono.

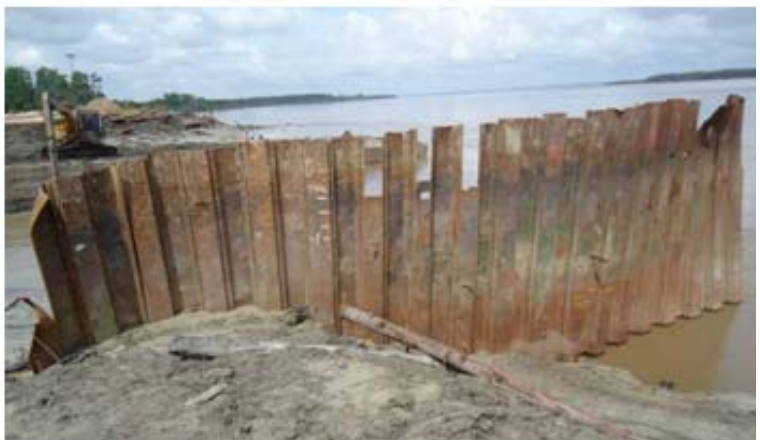

Gambar 2. Sheetpile yang mengalami kegagalan di lokasi dermaga. 


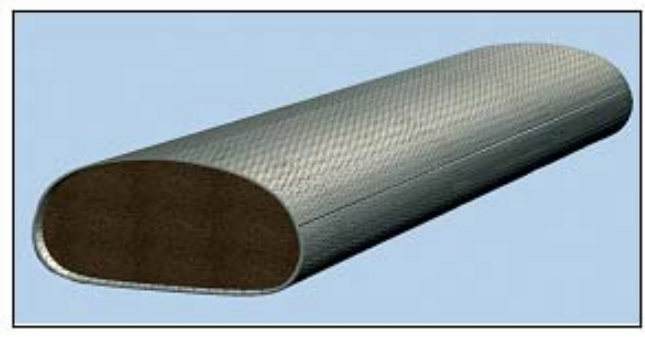

Gambar 3. Penampang tipikal Geotube.

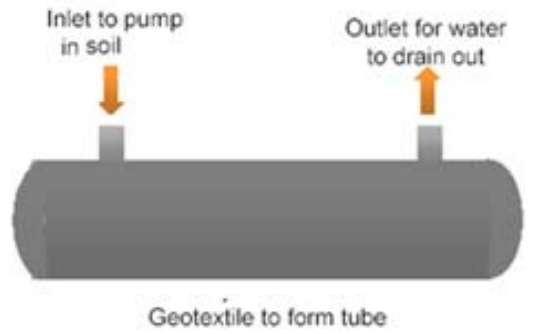

Gambar 4. Posisi inlet dan outlet Geotube.

Geotube memiliki kelebihan dari konstruksi lain, seperti: (1) biaya konstruksi lebih rendah; (2) waktu pelaksanaan konstruksi lebih cepat; (3) material pengisi dapat diperoleh dengan mudah di lokasi setempat (jika pasir tersedia); (4) pelaksanaan konstruksi dan pemasangan dapat dilakukan di dalam air dengan kedalaman tertentu.

\section{METODE}

Mula-mula sistem konstruksi Geotube dirancang. selanjutnya untuk menguji kelayakan sistem ini, analisis dilakukan menggunakan software Geocops guna menentukan jenis material geosintetik yang sesuai serta beberapa parameter lainnya seperti tekanan pompa. Perhitungan analitis lain yang dilakukan adalah perhitungan stabilitas global konstruksi melalui penggunaan software Slope/W serta perkiraan besarnya penurunan konsolidasi yang terjadi akan dilakukan dengan menggunakan teori konsolidasi 1 dimensi yang dipublikasikan oleh Terzaghi.

\section{HASIL DAN PEMBAHASAN}

\section{Perancangan Geotube}

\section{Data Lapangan}

Data tanah dasar berupa data hasil uji bor dan SPT serta hasil pengujian laboratorium. Berdasarkan data tersebut, dapat diketahui tanah dasar proyek ini merupakan lapisan tanah lempung dan terdapat lapisan kayu serta pasir. Berikut hasil uji bor pada proyek ini (Gambar 5).

Material pengisi Geotube merupakan tanah pasir dengan unit weight $17 \mathrm{kN} / \mathrm{m}^{3}$. Perbedaan elevasi pasang surut sekitar $4 \mathrm{~m}$. Kondisi lain yang harus diperhatikan adalah sebagai berikut: (1) arus pasang-surut berlumpur (Arus Bono) tinggi 4 meter dapat terjadi dua kali dalam sehari; (2) konstruksi merupakan areal ponton dan perahu bersandar dan sering terjadi proses sedimentasi.

\section{Parameter Perancangan}

Parameter-parameter yang diperlukan dalam perancangan Geotube (Gambar 6) adalah properti material pengisi dan tinggi gelombang rencana, untuk menentukan dimensi dan properti fisik geotekstil yang dibutuhkan untuk membuat Geotube (Pilarczyk, 2000). Material geotekstil yang digunakan sebagai bahan pembuat Geotube harus mempunyai kuat tarik yang tinggi untuk dapat menahan gaya pada saat proses pengisian tube. Selain itu, material ini juga harus mempunyai ukuran bukaan dan permeabilitas yang optimum agar air dapat dengan cepat keluar tapi material pengisi dapat 
tertahan. Perhitungan penentuan dimensi dan jenis material geosintetik dilakukan menggunakan bantuan program komputer yaitu GeoCops (Geosynthetic Confined Pressurized Slurry) (Leshchinsky \& Leshchinsky, 1996). Program ini memberikan output berupa geometri Geotube, keliling, longitudinal, dan kekuatan material yang dibutuhkan. Perhitungan sudah memperhitungkan faktor reduksi yang meliputi kekuatan jahitan, ketahanan, rangkak, dan resiko instalasi. Hasil analisis GeoCops adalah sebagai berikut (Gambar 7). Dari hasil analisis di atas, kuat tarik ultimit geotekstil yang diperlukan untuk membentuk Geotube setinggi $2,5 \mathrm{~m}$ adalah sebesar 192,9 kN/m.

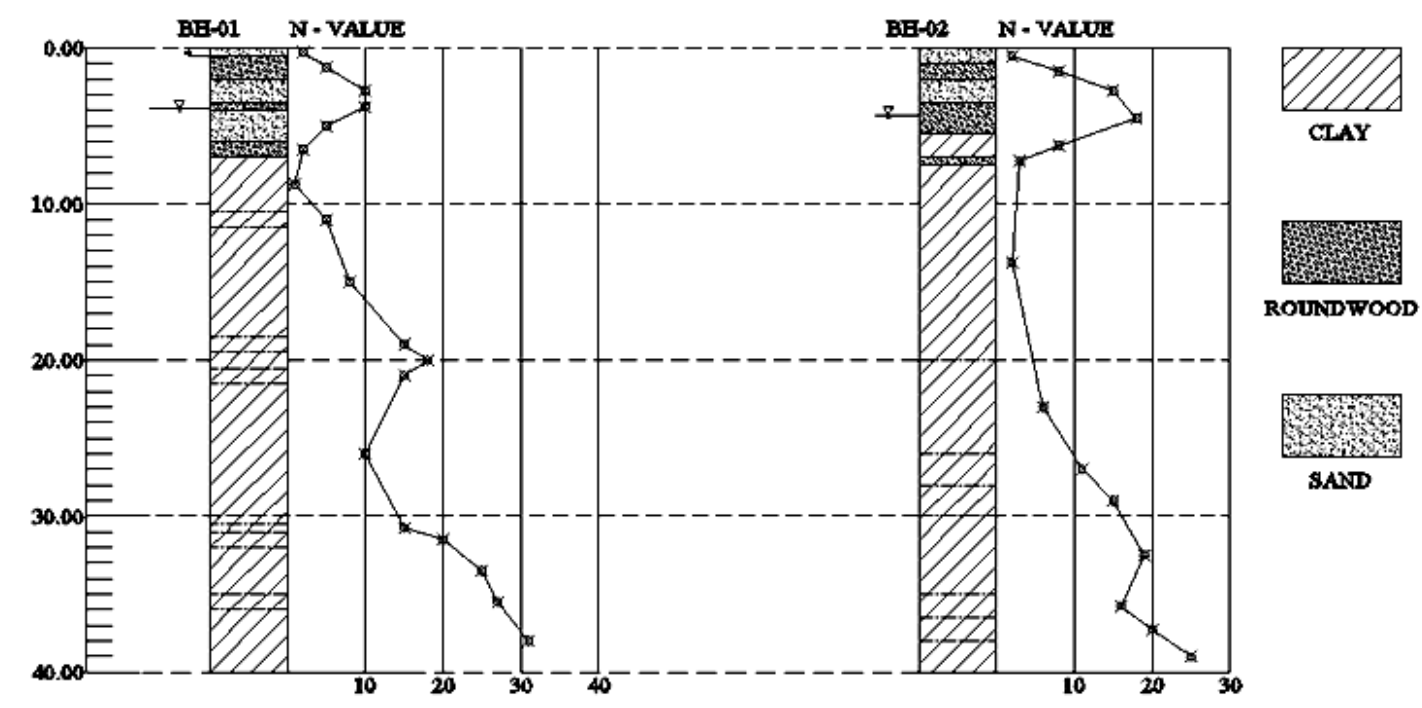

Gambar 5. Hasil uji bor dan SPT di lokasi proyek.

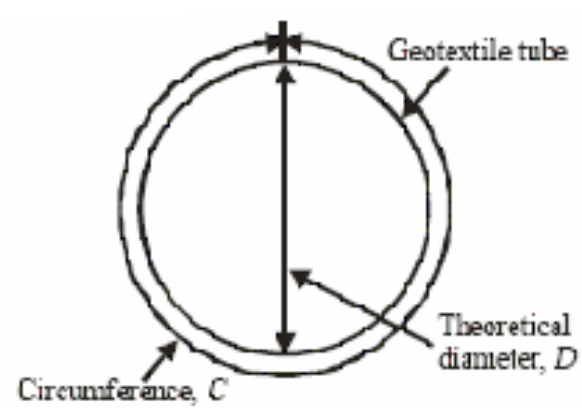

a) Fundamental geotextile tube parameters

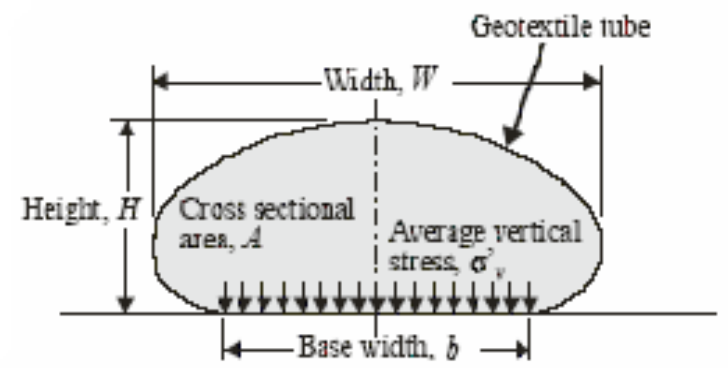

b) Engineering parameters of importance for filled geotextile tubes

Gambar 6. Parameter perancangan dimensi dan properti Geotube. 


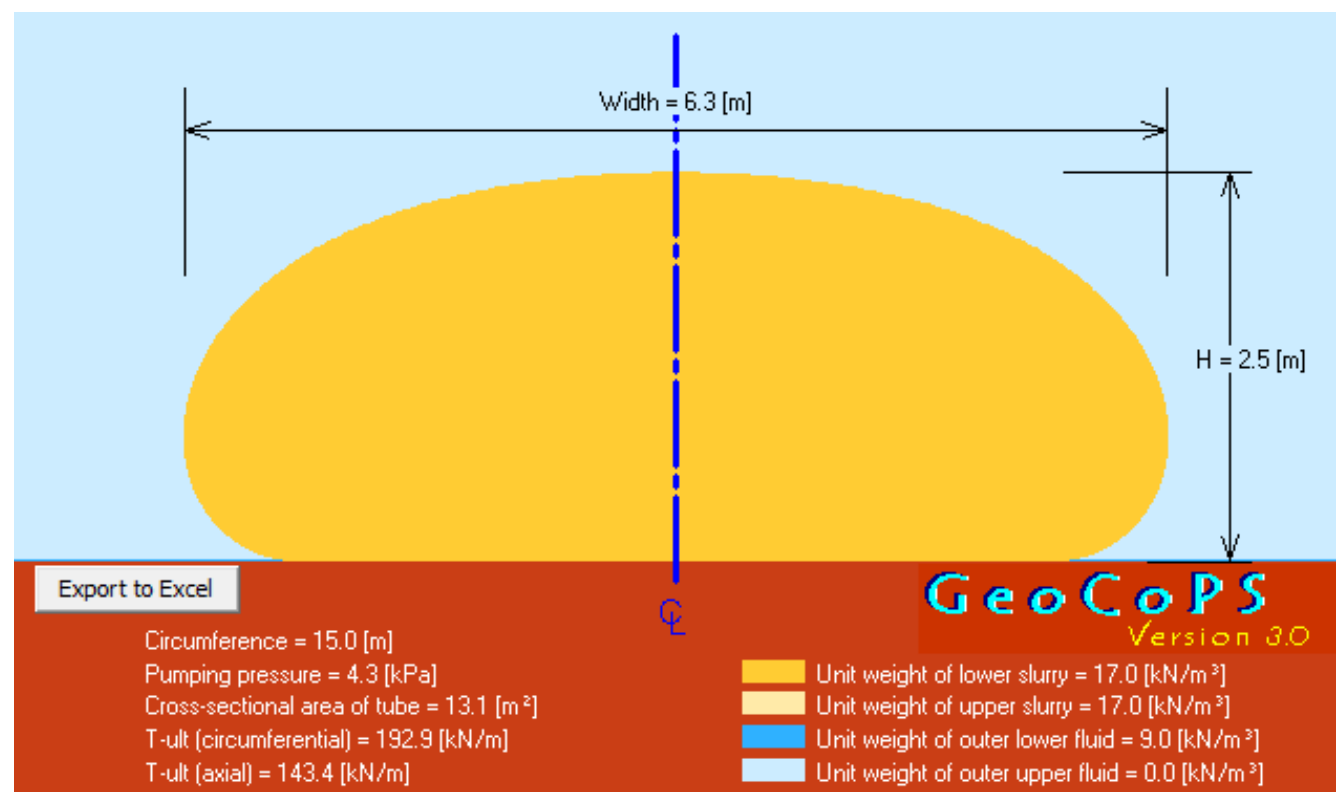

Gambar 7. Hasil analisis program GeoCops.

\section{Material Proteksi Geotube}

Material pembentuk Geotube terbuat dari polimer yang tidak tahan terhadap sinar UV. Konstruksi Geotube juga harus dilindungi terhadap benturan material tajam seperti batang-batang kayu yang hanyut atau benturan perahu kecil. Dengan mempertimbangkan kondisi dari tiap bagian yang dipasang Geotube, digunakan concrete mattrass untuk melindungi Geotube pada bagian yang rawan benturan serta material geomembran pada bagian yang minim benturan.

Material concrete mattresses merupakan komposit antara dua lapis material geotekstil yang mempunyai fungsi sebagai bekisting; dengan mortar beton sebagai material pengisinya. Material geomembran merupakan material kedap air yang terbuat dari polimer High Density Polyethylene yang mempunyai ketahanan yang baik terhadap zat kimia dan sinar UV. Material ini sangat fleksibel sehingga apabila terjadi penurunan setempat, material tidak akan rusak dan tetap berfungsi dengan baik. Berdasarkan posisi dan elevasinya, pemasangan Geotube ini dibagi menjadi beberapa tipe sebagai berikut (Gambar 8 - 12).

\section{Analisis Stabilitas}

Tahap perancangan berikutnya adalah analisis stabilitas konstruksi Geotube (Chu et al., 2011, Das, 2002, Pilarczyk, 2000), meliputi stabilitas geser, stabilitas guling, dan stabilitas global (Gambar 13). Dengan memperhitungkan gaya-gaya yang bekerja pada Geotube, hasil perhitungan angka keamanan adalah sebagai berikut (Tabel 1). Stabilitas global dihitung dengan bantuan program Slope/W menggunakan metode Bishop dan menghasilkan angka keamanan sebagai berikut (Gambar 14 dan 15). 


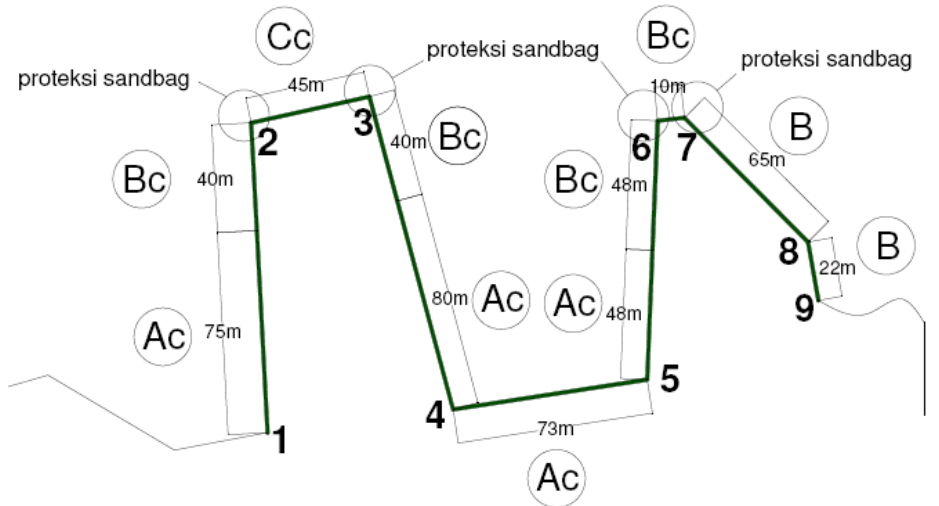

Gambar 8. Pembagian tipe pemasangan Geotube berdasarkan posisinya.

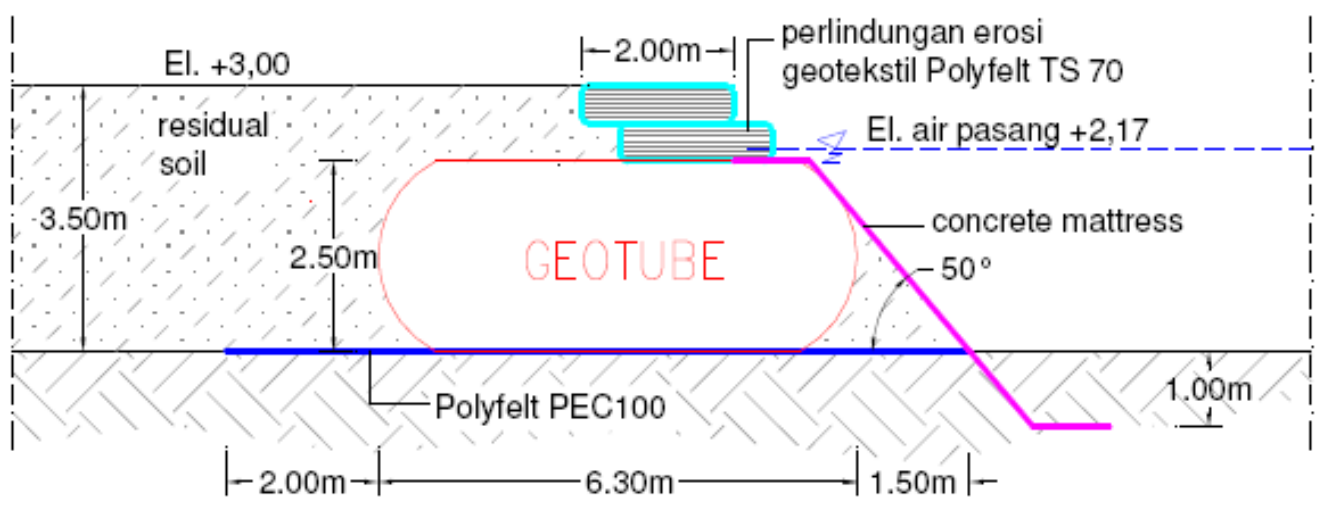

Gambar 9. Penampang tipikal konstruksi Ac.

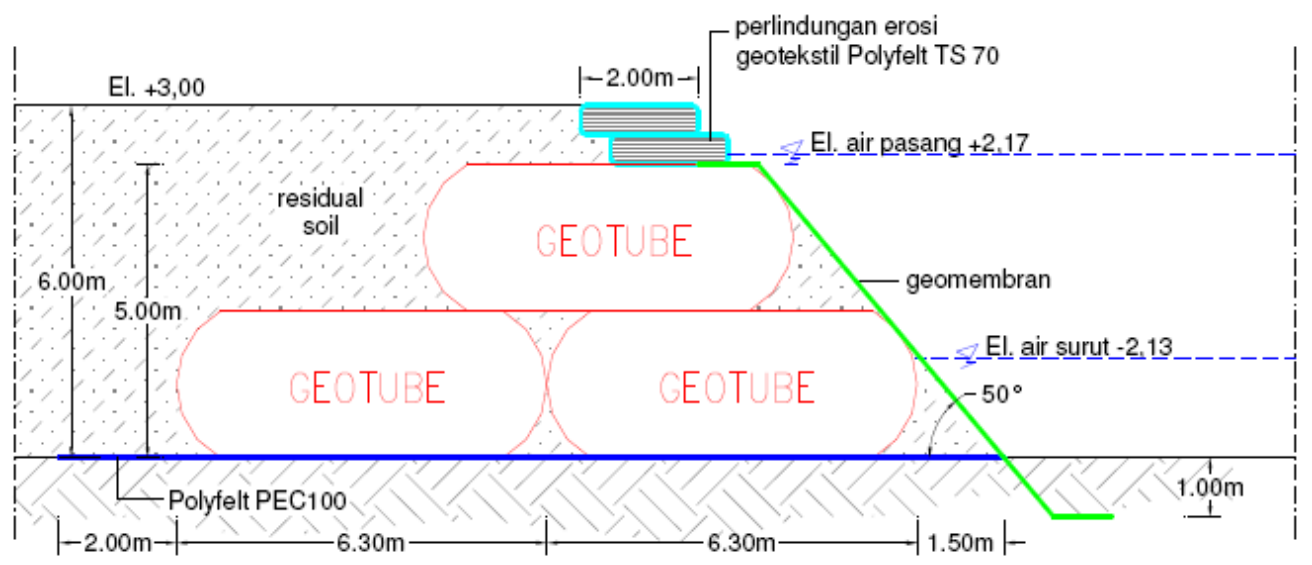

Gambar 10. Penampang tipikal konstruksi B. 


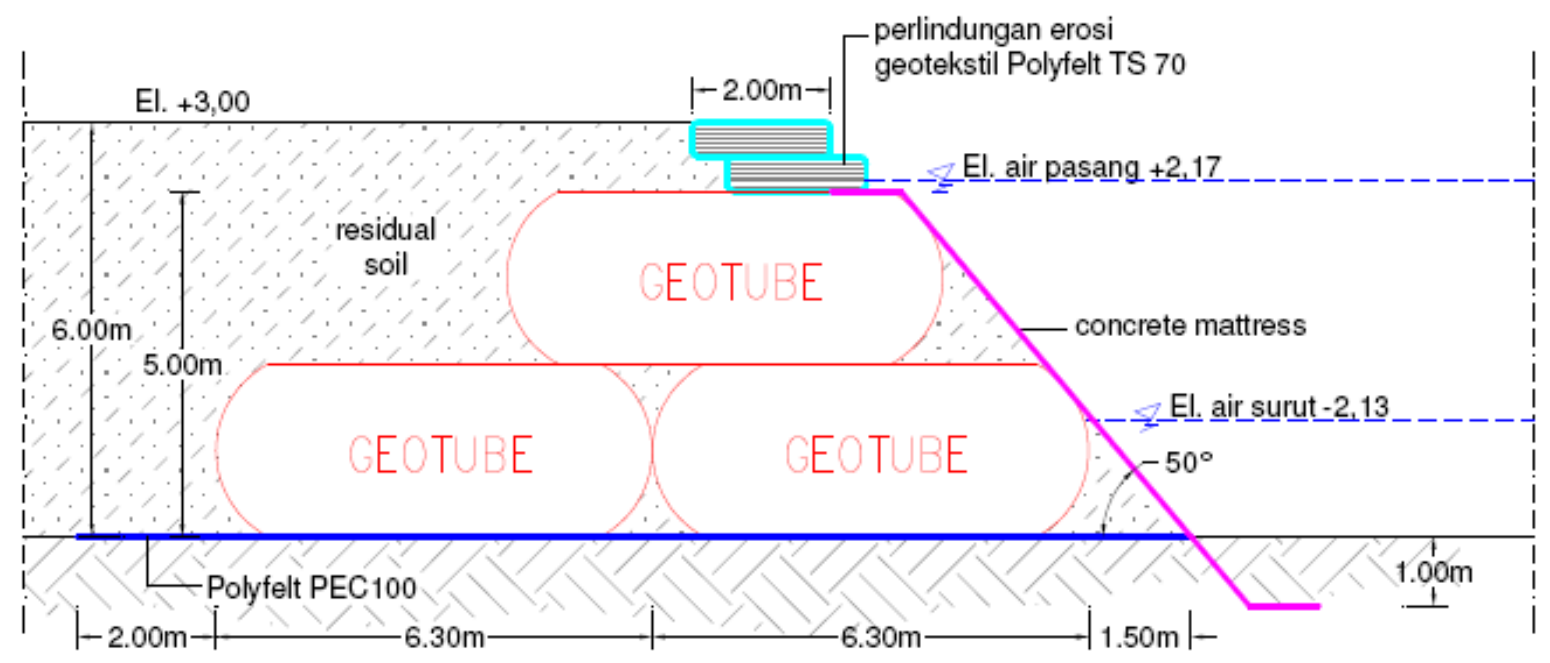

Gambar 11. Penampang tipikal konstruksi Bc.

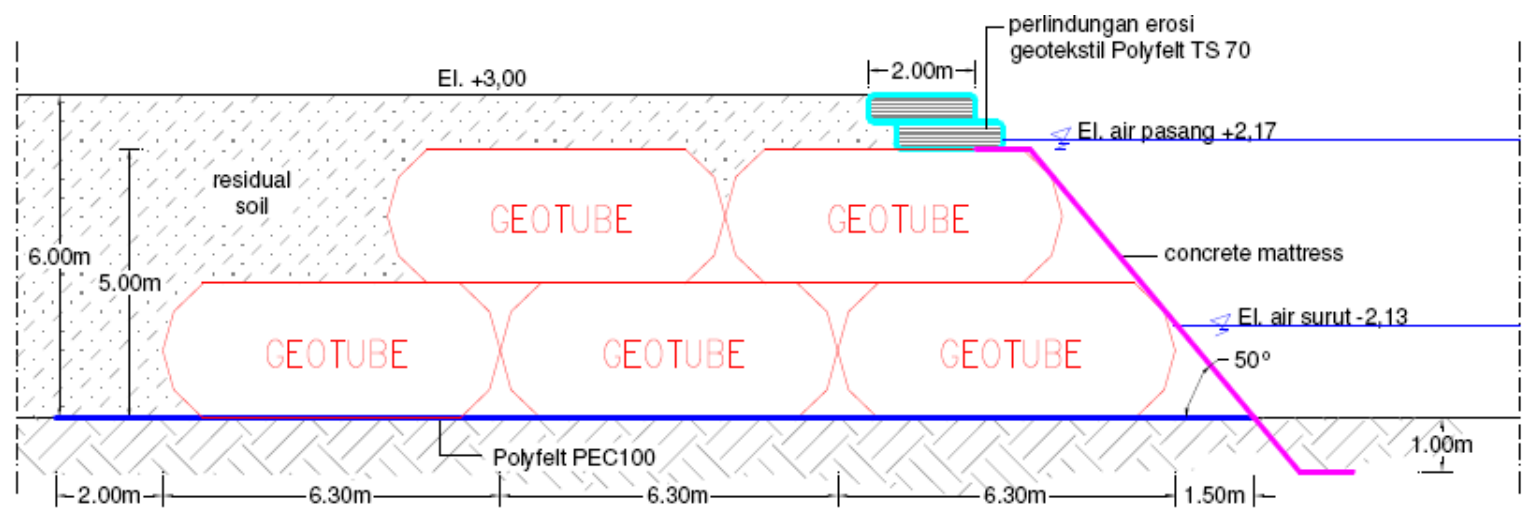

Gambar 12. Penampang tipikal konstruksi Cc.

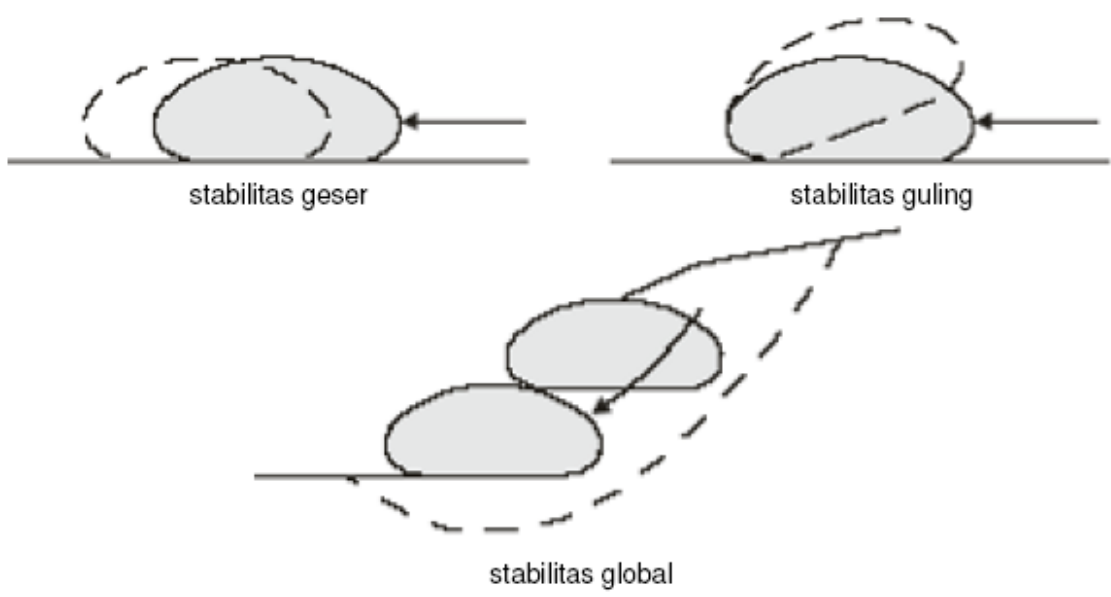

Gambar 13. Kriteria stabilitas yang ditinjau. 
Tabel 1

Angka Keamanan

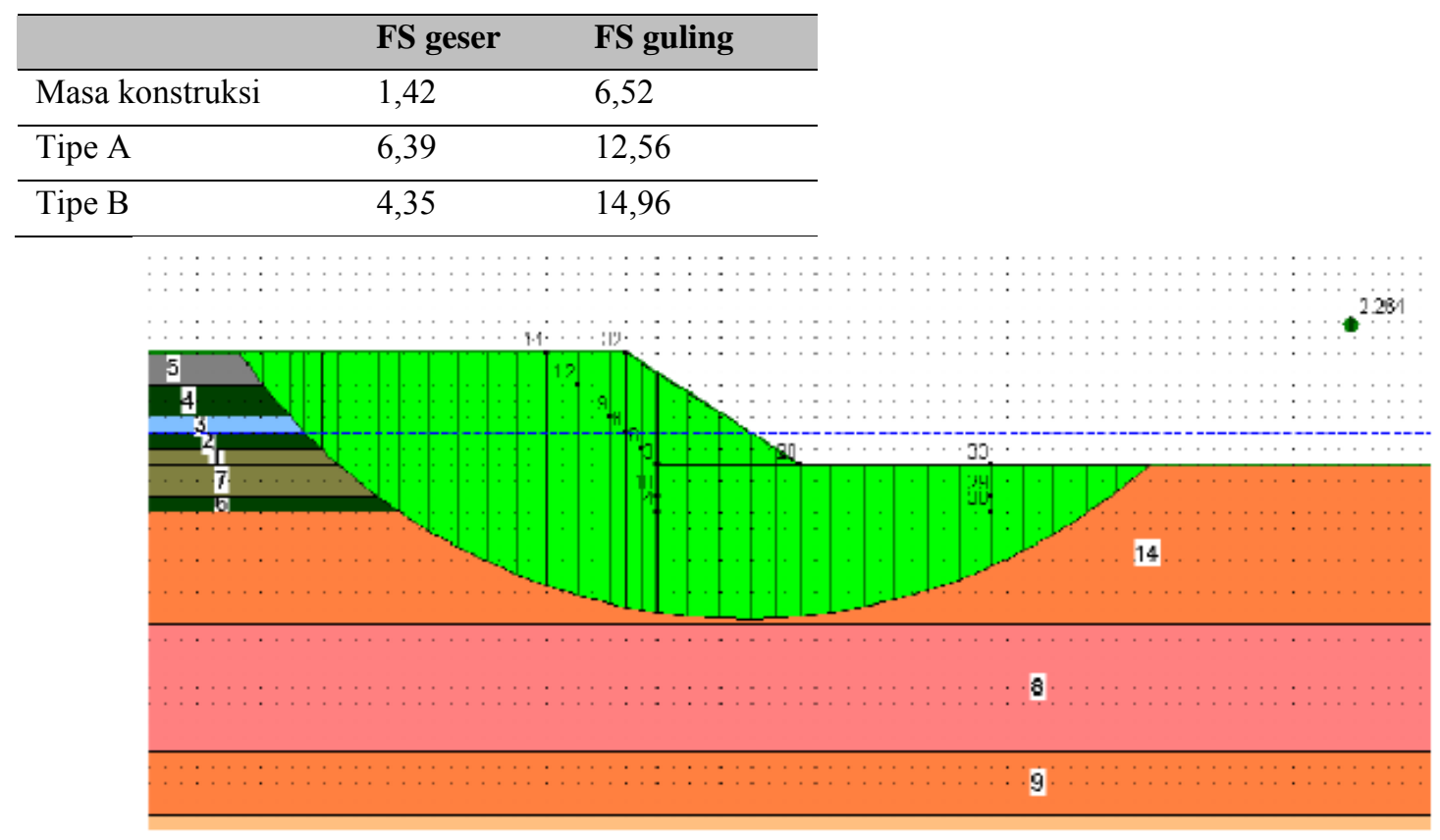

Gambar 14. Hasil analisis konstruksi Tipe A $(\mathrm{FS}=2,26)$.

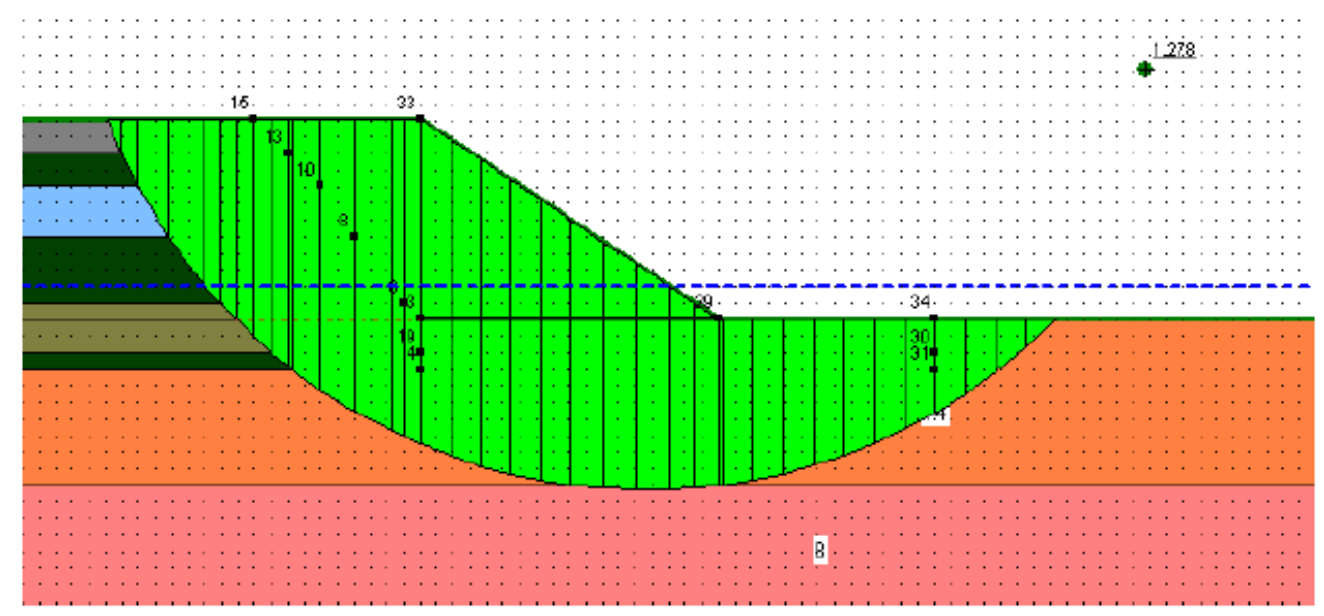

Gambar 15. Hasil analisis konstruksi Tipe B $(\mathrm{FS}=1,28)$.

\section{Perhitungan Konsolidasi}

Penurunan konsolidasi dihitung menggunakan Teori Konsolidasi 1D dari Terzaghi dengan persamaan-persamaan sebagai berikut.

Kondisi Normally Consolidated $\left(\mathrm{P}_{\mathrm{o}} \approx \mathrm{P}_{\mathrm{c}}\right)$ 


$$
S=\frac{c_{c}}{1+e_{o}} \cdot H \cdot \log \left(\frac{P_{o}+\Delta P}{P_{o}}\right)
$$

Kondisi Overconsolidated

Overconsolidated I : $\mathrm{P}_{\mathrm{o}}+\Delta \mathrm{P}<\mathrm{P}_{\mathrm{c}}$

$$
S=\frac{C_{s}}{1+e_{o}} \cdot H \cdot \log \left(\frac{P_{o}+\Delta P}{P_{o}}\right)
$$

- Overconsolidated II : $\mathrm{P}_{\mathrm{o}}<\mathrm{P}_{\mathrm{c}}<\mathrm{P}_{\mathrm{o}}+\Delta \mathrm{P}$

$$
S=\frac{C_{s}}{1+e_{o}} \cdot H \cdot \log \left(\frac{P_{c}}{P_{o}}\right)+\frac{C_{c}}{1+e_{o}} \cdot H \cdot \log \left(\frac{P_{o}+\Delta P}{P_{c}}\right)
$$

dimana:

$$
\begin{aligned}
& \mathrm{S}=\text { perkiraan penurunan konsolidasi } \\
& \mathrm{c}_{\mathrm{c}}=\text { indeks kompresi } \\
& \mathrm{c}_{\mathrm{s}}=\text { indeks muai } \\
& \mathrm{e}_{\mathrm{o}}=\text { angka pori mula-mula } \\
& \mathrm{H}=\text { tebal lapisan tanah yang terkompresi } \\
& \mathrm{P}_{\mathrm{o}}=\text { tekanan overburden tanah } \\
& \mathrm{P}_{\mathrm{c}}=\text { tekanan prakonsolidasi } \\
& \Delta \mathrm{P}=\text { tambahan tekanan dari beban luar }
\end{aligned}
$$

Hasil perhitungan konsolidasi disajikan dalam grafik berikut (Gambar 16). Penurunan konsolidasi $90 \%$ diperkirakan sebesar $\pm 37 \mathrm{~cm}$ dan terjadi dalam jangka waktu $70-72$ tahun.

\section{Proses Instalasi}

Pengisian Geotube menggunakan sebuah hooper yang pada prinsipnya mengalirkan cairan pengisi dengan tekanan yang berasal dari pompa dan pengaruh ketinggian (Peurifoy dan Schexnayder, 2002). Untuk memberikan output air bertekanan tinggi, digunakan sebuah pompa yang memiliki kapasitas $300 \mathrm{~m}^{3} / \mathrm{jam}$. Kemudian dilakukan penggelaran material Geotube (Gambar 17) dan dilakukan pemompaan (Gambar 18) sampai tinggi rencana Geotube tercapai (Gambar 19). Gambar 20 merupakan tipikal konstruksi dengan proteksi geomembran, sedangkan tipikal konstruksi dengan proteksi concrete mattrass dapat dilihat pada Gambar 21.

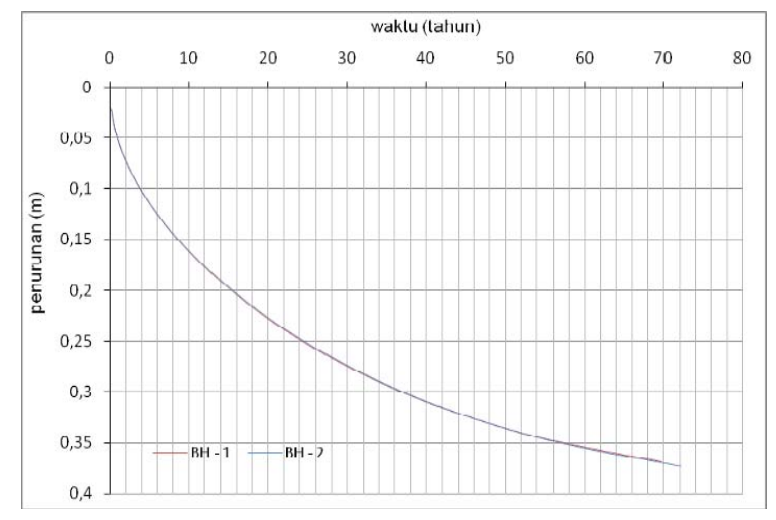

Gambar 16. Grafik hasil perhitungan konsolidasi.

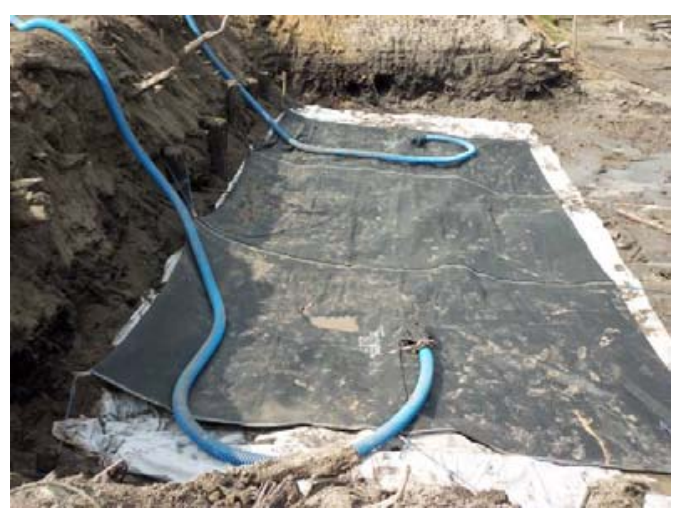

Gambar 17. Penggelaran material Geotube. 


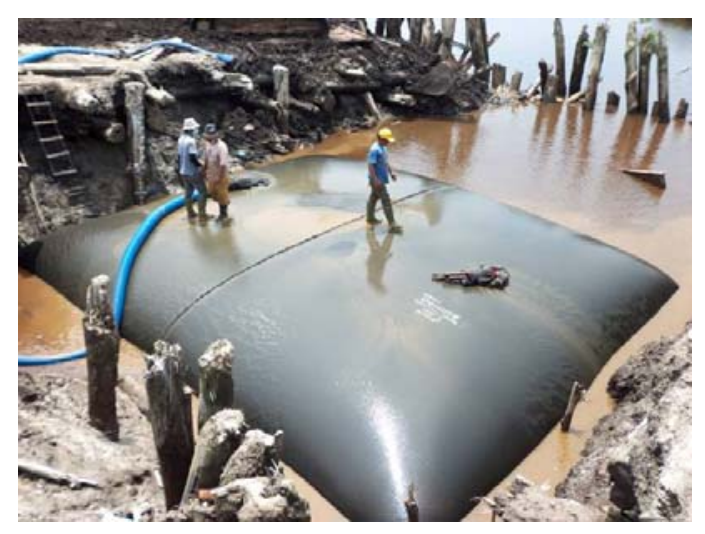

Gambar 18. Proses pemompaan pasir ke dalam Geotube.

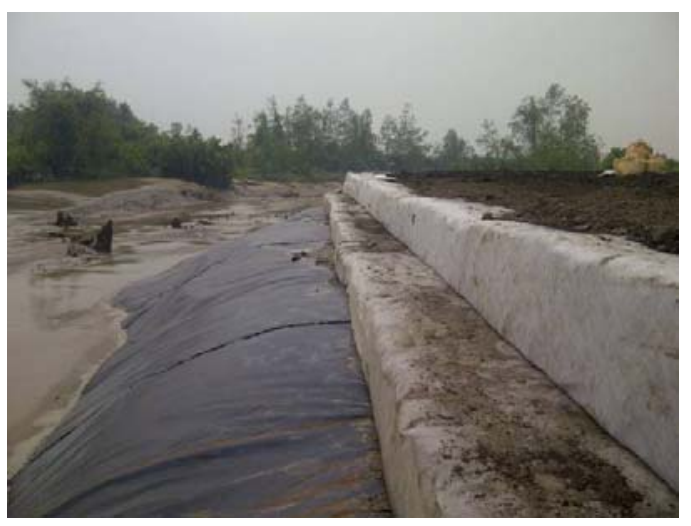

Gambar 20. Tipikal konstruksi dengan proteksi geomembran.

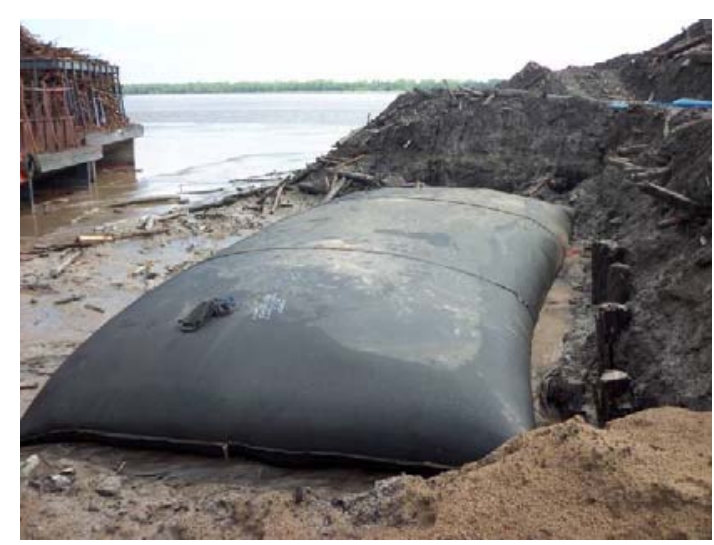

Gambar 19. Geotube yang selesai diisi sampai ketinggian rencana.

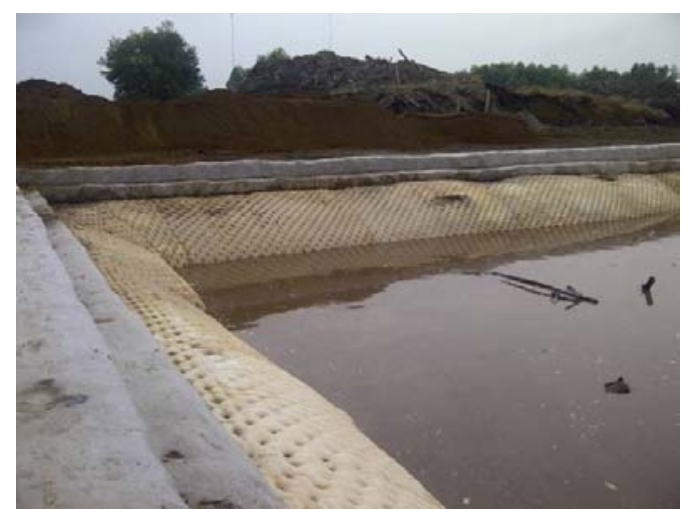

Gambar 21. Tipikal konstruksi dengan proteksi concrete mattress.

\section{Kendala}

Beberapa kendala yang ditemukan selama proses instalasi antara lain: (1) proses persiapan lahan membutuhkan waktu yang cukup lama akibat ditemukan berbagai objek seperti bangkai kapal dan potongan-potongan kayu besar. Objek-objek ini harus dibuang sehingga konstruksi geotube duduk di atas tanah yang stabil; (2) pasir pengisi mengandung banyak sampah dan potongan kayu yang dapat mengganggu proses pengisian jika menggunakan pompa. Sebagai solusi dari permasalahan ini, proses pengisian menggunakan hooper yang mengandalkan gaya gravitasi; (3) perbedaan tinggi air pasang surut yang cukup signifikan menyebabkan proses pelaksanaan geotube sedikit terhambat terutama pada bagian yang terendam air.

\section{PENUTUP}

Dari hasil analisis dan pelaksanaan di lapangan, beberapa kesimpulan yang dapat diambil adalah sebagai berikut: (1) selama masa pelaksanaan dan masa pelayanan sampai saat ini, terbukti konstruksi Geotube dapat menahan gaya akibat gelombang arus pasang bono dan melindungi bantaran sungai. Aplikasi Geotube merupakan alternatif solusi konstruksi proteksi erosi yang efektif; (2) metode dan alat untuk pengisian geotube harus disesuaikan dengan kondisi lapangan. 


\section{DAFTAR PUSTAKA}

Bergado, D.T. (2005). Protection, Mitigation and Rehabilitation of Coastal and Waterway Erosion Control. Proceedings of the International Symposium on Tsunami Reconstruction with Geosynthetics. Bangkok: ACSIG.

Chu, J., Guo, W., \& Yan, S.W. (2011). Geosynthetic Tubes and Geosynthetic Mats: Analyses and Application. Geotechnical Engineering Journal of the SEAGS \& AGSSEA 42 (1), March 2011 ISSN 0046-5828. China: Nanyang Technological University.

Das, B. M. (2002). Principles of Geotechnical Engineering ( $5^{\text {th }}$ edition). Florence: Thomson Brooks/Cole.

Koerner, R. M. (2005). Designing With Geosynthetics ( $5^{\text {th }}$ edition). New Jersey: Pearson/Prentice Hall.

Leshchinsky, Dov \& Leshchinsky, Ora. (1996). GeoCoPS (2.0): Supplemental Notes. Newark: Adama Engineering.

Peurifoy, R. L. dan Schexnayder, C. J. (2002). Construction Planning, Equipment, and Methods (6 ${ }^{\text {th }}$ edition). New York: McGraw Hill.

Pilarczyk, K.W., (2000). Geosynthetics and Geosystems in Hydraulic and Coastal Engineering. A.A. Rotterdam: Balkema Publishing. 